\title{
Estrogen receptors $\alpha$ and $\beta$ in the normal, hyperplastic and carcinomatous human prostate
}

\author{
M Royuela, M P de Miguel, F R Bethencourt ${ }^{1}$, M Sánchez-Chapado ${ }^{1}$, \\ B Fraile, M I Arenas and R Paniagua \\ Department of Cell Biology and Genetics, University of Alcalá, E-28871 Alcalá de Henares, Madrid, Spain \\ ${ }^{1}$ Department of Urology, Hospital Príncipe de Asturias, E-28871 Alcalá de Henares, Madrid, Spain \\ (Requests for offprints should be addressed to R Paniagua, Department of Cell Biology and Genetics, University of Alcalá, \\ E-28871 Alcalá de Henares, Madrid, Spain)
}

\begin{abstract}
Two different estrogen receptors (ER- $\alpha$ and ER- $\beta$ ) have been described, which are differentially involved in regulating the normal function of reproductive tissues. ER- $\alpha$ was considered for a long time to be the only estrogen receptor, and it has been detected in the stromal cells of the human prostate but not in the epithelium. To obtain new information about the differential effects of both receptor types, we have investigated their localization in normal prostates, benign prostatic hyperplasia $(\mathrm{BPH})$, and prostatic cancer (PC) by immunohistochemistry, ELISA and Western blot. Epithelial immunostaining was absent in normal prostates and was present in BPH (10\% of cells) and PC ( $80 \%$ of cells), whereas about $15 \%$ of stromal cells were positively immunostained for ER- $\alpha$ in the three
\end{abstract}

types of prostatic specimens studied. Epithelial immunostaining for ER- $\beta$ was detected in normal prostates $(13 \%$ of cells), BPH (30\% of cells) and PC (79\% of cells), whereas stromal immunostaining for ER- $\beta$ was absent in normal and hyperplastic prostates and was present in PC $(12 \%$ of cells). The complementary presence of both receptor types in the normal prostate $(E R-\beta$ in the epithelium and ER- $\alpha$ in the stroma) might explain the mechanism of estrogen action in the development of BPH. The increased epithelial immunostaining for both ER- $\alpha$ and $\mathrm{ER}-\beta$ in $\mathrm{BPH}$ and PC suggests that the involvement of estrogen receptors in hyperplasia and cancer concerns mainly the epithelium.

Journal of Endocrinology (2001) 168, 447-454

\section{Introduction}

Estrogen therapy or orchidectomy have been the standard treatments for advanced prostate cancer in the last four decades (Cox \& Crawford 1995). However, the exact mechanism of estrogen action in the prostate is not yet completely understood. This might be partially attributed to the lack of functional studies, together with controversial immunocytochemical data regarding the localization of estrogen receptors (ERs).

ERs are members of a nuclear receptor superfamily of ligand-activated transcription factors (Hobisch et al. 1997). At present, two different ERs (ER- $\alpha$ and ER- $\beta$ ) have been described and they have been shown to be critically and differentially involved in the regulation of the normal function of reproductive tissues (Mosselman et al. 1996, Byers et al. 1997). For a long time, ER- $\alpha$ was assumed to be the only estrogen receptor. In humans, this receptor has a molecular mass of $66 \mathrm{kDa}$ (Green et al. 1986) and shows $88 \%$ homology with the rat ER- $\alpha$ (Koike et al. 1987). ER- $\alpha$ has been demonstrated in human prostate, but results from different groups are contradictory. Several authors have confined this receptor to the stromal compartment of the prostate (Bashirelahi et al. 1979, Ehara et al. 1995), whereas others have also localized it in the epithelial compartment (Schulze \& Claus 1990). There is also no agreement on the association between ER- $\alpha$ and prostatic neoplasia, since this receptor has been demonstrated in several prostate cancer cell lines (Carruba $e t$ al. 1994, Castagnetta \& Carruba 1995, Srinivasan et al. 1995) but not in others (Brolin et al. 1992, Konishi et al. 1993, Hobisch et al. 1997).

Recently, a gene that encodes another estrogen receptor (ER- $\beta$ of $54.2 \mathrm{kDa}$ ) has been cloned from a rat prostate cDNA library (Kuiper et al. 1996), and a human homolog of rat ER- $\beta$ cDNA has been obtained from human testis (Mosselman et al. 1996). Structurally, ER- $\beta$ is highly homologous to ER- $\alpha$ in the DNA binding domain (95\% amino-acid identity) but shows only $60 \%$ homology in the ligand binding domain (Kuiper et al. 1998). The finding of this second receptor prompts a re-evaluation of the molecular basis for estrogen action (Kuiper et al. 1996), since ER- $\beta$ has been demonstrated to be the most predominant ER in the rat prostate (Kuiper et al. 1998). 
To obtain new information about the different effects of both ER types, we have investigated their localization in normal prostates, benign prostatic hyperplasia $(\mathrm{BPH})$, and prostatic cancer (PC) by immunohistochemistry, ELISA and Western blot.

\section{Materials and Methods}

\section{Materials}

The material used was: (a) histologically normal prostates obtained at autopsy (8-10 h after death) from 15 men (aged 20-38 years) without histories of reproductive, endocrine or related diseases; (b) prostatic biopsies from 25 men (aged 53-88 years) diagnosed clinically and histopathologically to have benign prostatic hyperplasia (BPH); and (c) prostatic biopsies from 25 men (aged 54-69 years) diagnosed for prostatic cancer (PC, dominant Gleason grade 3, Gleason score 5-7). The patients did not receive hormonal therapy before prostatectomy and were not diagnosed for metastatic cancer. Each sample was divided into three portions: one portion was immediately processed for immunohistochemistry, and the other two portions were frozen in liquid nitrogen and maintained at $-80{ }^{\circ} \mathrm{C}$ for ELISA and Western blot analysis. Removal of tissues and the study of autopsy samples were approved by the Ethics Committee of the Hospital and were made with the consent of the patients' relatives.

\section{Methods}

Primary antibodies Immunochemical studies (Western blot, ELISA, and immunohistochemistry) were carried out using either mouse monoclonal antibody against human ER- $\alpha$, or goat polyclonal antibody (purified from breast cancer cells) against ER- $\beta$. Both antibodies were purchased from Santa Cruz Biotechnologies (Santa Cruz, CA, USA).

Western blot Western blot analysis of each prostate was performed. Tissues were homogenized in the extraction buffer $(0.05 \mathrm{M}$ Tris $-\mathrm{HCl}, \mathrm{pH} 8)$ with the addition of a cocktail of protease inhibitors $(10 \mathrm{mM}$ iodoacetamide, $100 \mathrm{mM}$ phenylmethyl sulfonic fluoride, $0.01 \mathrm{mg} / \mathrm{ml}$ soybean trypsin inhibitor and $1 \mu \mathrm{l} / \mathrm{ml}$ leupeptin) in the presence of $0.5 \%$ Triton X-100. Homogenates were centrifuged for $10 \mathrm{~min}$ at 10000 r.p.m. Supernatants were mixed with an equivalent volume of SDS buffer $(10 \%$ SDS in Tris- $\mathrm{HCl}, \mathrm{pH} 8$, containing $50 \%$ glycerol, $0.1 \mathrm{mM}$ 2-beta-mercaptoethanol and $0 \cdot 1 \%$ bromophenol blue). Then the mixture was denatured for $5 \mathrm{~min}$ at $100{ }^{\circ} \mathrm{C}$, and $10 \mu \mathrm{l}$ aliquots of the homogenate were separated in SDS-polyacrylamide slab minigels (15\% gradient gels). Separated proteins were transferred to nitrocellulose membranes in the transfer buffer ( $25 \mathrm{mM}$ Tris- $\mathrm{HCl}, 192 \mathrm{mM}$ glycine, $0 \cdot 1 \%$ SDS and 20\% methanol). Membranes $(0.2 \mu \mathrm{m})$ were blocked with $3 \%$ BSA dissolved in TBST buffer $(10 \mathrm{mM}$ Tris-HCl, $150 \mathrm{mM} \mathrm{NaCl}, 0 \cdot 05 \%$ Tween $20, \mathrm{pH} 8$ ) overnight at $37^{\circ} \mathrm{C}$, and then incubated with the primary antibodies at $1: 250($ ER- $\alpha)$ or $1: 100($ ER- $\beta)$ dilution in blocking solution for $3 \mathrm{~h}$. After extensive washing with TBST, the membranes were incubated with biotin-conjugated anti-mouse (Vector Laboratories, Burlingame, CA, USA) or anti-goat (Santa Cruz) immunoglobulins for $1 \mathrm{~h}$ at room temperature, and then washed and incubated with the avidinbiotin-peroxidase complex (Vector) at 1:1000 dilution. The membranes were developed with an enhanced chemiluminescence (ECL) kit, following the procedure described by the manufacturer (Amersham International, Amersham, Bucks, UK). The staining intensity (optical density) of each band was measured with an automatic image analyzer (MIP4, version $4 \cdot 4$, Consulting Image Digital, Barcelona, Spain) in order to compare the expression of each protein in the three different prostate groups. The average values obtained for each group were compared by ANOVA, and the significance of differences between groups were evaluated by the Fisher and Behrens' test. As negative controls of immunoreactions to each antibody, homogenized tissues from the three types of prostates were incubated with the corresponding blocking peptide (Santa Cruz). As positive controls, blots of rat ovarian tissue were performed using the same antibodies.

ELISA An enzyme-linked immunoassay (ELISA) of each prostate was carried out. Protein concentrations were calculated by the Bradford (1976) method and were diluted to $4 \cdot 125 \mu \mathrm{g} / \mu \mathrm{l}$. Serial dilutions of proteins from each prostate were made and incubated on a 96-well multiplate overnight at $4{ }^{\circ} \mathrm{C}$. The plates were washed with TBST, blocked with $1 \%$ bovine serum albumin in TBS for $1 \mathrm{~h}$ at room temperature, and incubated with the first antibodies at 1:2000 (anti-ER- $\alpha$ ) and 1:1000 (anti-ER- $\beta$ ) dilution for $3 \mathrm{~h}$ also at room temperature. After a new wash, the biotin-conjugated anti-mouse (Vector) or antigoat (Santa Cruz) immunoglobulins were added to each well, incubated for $1 \mathrm{~h}$ at room temperature, and then washed and incubated with the avidin-biotin-peroxidase complex (Vector). The interactions were visualized with 0.05\% 2,2 azino di-3-ethylbenzthiazholine sulfonic acid (ABTS) (Sigma, Barcelona, Spain) in $100 \mathrm{mM}$ citrate buffer, $\mathrm{pH}$ 5. Optical density values at $405 \mathrm{~nm}$ were obtained in a spectrophotometer (Multiskan Bichromatic, Labsystems, Finland). The means \pm S.D. for each prostate group (normal, benign prostatic hyperplasia, and prostatic carcinoma) were calculated and represented. The average optical density values corresponding to $4 \cdot 125 \mu \mathrm{g} / \mu \mathrm{l}$ protein obtained for each group were compared by ANOVA and the significance of differences between groups was evaluated by the Fisher and Behrens' test. 
Table 1 Comparison of immunostaining intensities (measured as average optical density \pm S.D.) in Western blot analyses of normal prostates, benign prostatic hyperplasia, and prostatic carcinoma

\begin{tabular}{|c|c|c|c|}
\hline & $\begin{array}{l}\text { Normal } \\
\text { prostate }\end{array}$ & $\begin{array}{l}\text { Benign prostatic } \\
\text { hyperplasia }\end{array}$ & $\begin{array}{l}\text { Prostatic } \\
\text { carcinoma }\end{array}$ \\
\hline \multicolumn{4}{|l|}{ Estrogen receptor } \\
\hline ER- $\alpha$ & $1 \cdot 778 \pm 146^{\mathrm{a}}$ & $3 \cdot 867 \pm 422^{b}$ & $6 \cdot 081 \pm 774^{\mathrm{c}}$ \\
\hline ER- $\beta$ & $4 \cdot 542 \pm 533^{d}$ & $6 \cdot 024 \pm 686^{e}$ & $8 \cdot 119 \pm 959^{f}$ \\
\hline
\end{tabular}

For each receptor, values with a different superscript letter differ significantly $(P \leq 0 \cdot 05)$. The mean values and S.D. for each group have been calculated from all samples corresponding to the group.

Immunohistochemistry For immunohistochemistry, tissues were fixed in a $0 \cdot 1 \mathrm{M}$ phosphate-buffered $10 \%$ formaldehyde solution for $24 \mathrm{~h}$, dehydrated, and embedded in paraffin. Sections, 5- $\mu$ m-thick, were processed following the avidin-biotin-peroxidase complex (ABC) method (Hsu et al. 1981). Microwave antigen retrieval was performed. Briefly, after deparaffinization, sections were hydrated, incubated for $30 \mathrm{~min}$ in $0.3 \% \mathrm{H}_{2} \mathrm{O}_{2}$ in methanol to inhibit endogenous peroxidase activity and microwave irradiated five times at $1300 \mathrm{~W}$ in $10 \mathrm{mM}$ citrate buffer at pH 5.8 during $2.5 \mathrm{~min}$, allowing the sections to cool down between microwave cycles. After rinsing in TBS buffer, the slides were incubated with normal goat or mouse serum at 1:5 dilution in TBS containing 5\% BSA for $30 \mathrm{~min}$ to prevent non-specific binding of the first antibody. The sections were then incubated overnight at $4{ }^{\circ} \mathrm{C}$ with the primary antibody (ER- $\alpha$ or ER- $\beta$ ), diluted in TBS containing 1\% BSA. The primary antibody dilutions found to be optimal for this study were 1:300 for ER- $\alpha$, and 1:25 for ER- $\beta$. The sections were then washed in TBS and incubated with rabbit anti-mouse (ER- $\alpha$ ) or donkey anti-goat $(\mathrm{ER}-\beta)$ biotinylated immunoglobulins (Santa Cruz). Later on, the sections were incubated with avidin-biotin-peroxidase complex (Vector) for $30 \mathrm{~min}$ and developed with diaminobenzidine (DAB, Sigma), using the glucose oxidase-DAB-nickel intensification method (Hsu \& Soban 1982). After this, sections were dehydrated and mounted in DePeX (Probus, Badalona, Spain). Care was always taken to develop the sections of the different pathological and non-pathological conditions for exactly the same time in each immunohistochemical reaction.

The specificity of the immunohistochemical procedures was checked using negative and positive control sections. For negative control of immunoreactions, adjacent sections of each type (normal, $\mathrm{BPH}$, and prostatic cancer) were incubated with the corresponding blocking peptide for each antibody (Santa Cruz). As positive controls, sections of rat ovary were incubated with the same antibodies.

A histological comparative quantification of immunolabeling in normal, hyperplastic, and neoplastic prostates was performed for each of the two antibodies. From each normal prostate specimen, 6 histological sections of each region (central, intermediate and peripheral) were selected at random. In each section, the percentage of immunolabeled nuclei (in a total of 1000 nuclei examined per region) was calculated by two different observers using the $\times 40$ objective. Of the average values obtained for each prostate specimen, the mean \pm S.D. for the normal prostate group was calculated. The same quantitative study was carried out in the hyperplastic and neoplastic prostates, although the number of sections per prostatic region used was greater (23 in $\mathrm{BPH}$ and 29 in PC), and all the sections were taken from the impaired zone. In PC specimens, areas showing a papillary pattern and areas showing a microglandular pattern were studied separately. In the study, the number of sections was determined by successive approaches to obtain the minimum number required to reach the lowest S.D. The statistical significance between means was assessed by ANOVA and the Fisher and Behrens' test.

\section{Results}

\section{Western blot}

The results of Western blot analyses are shown in Table 1 and Fig. 1. The antibodies used showed a single band, at approximately 66 and $55 \mathrm{kDa}$ for $\mathrm{ER}-\alpha$ and $\mathrm{ER}-\beta$ respectively, in the three groups of men studied and in the rat ovary used as a positive control. Comparison of optical densities revealed significant differences $(P \leq 0 \cdot 05)$ between the three groups of prostates. The highest optical density was found for PC specimens, and the lowest for normal prostates.

\section{ELISA}

The results of the ELISA study showed a linear correlation between increasing concentrations of the homogenized tissues and their respective optical densities (Fig. 2). For both antibodies, the optical density in $4 \cdot 125 \mu \mathrm{g} / \mu \mathrm{l}$ protein was significantly increased $(P \leq 0 \cdot 05)$ in both $\mathrm{PC}$ and $\mathrm{BPH}$ compared with normal prostates. Comparison between the 
ER- $\alpha \quad$ ER- $\beta$

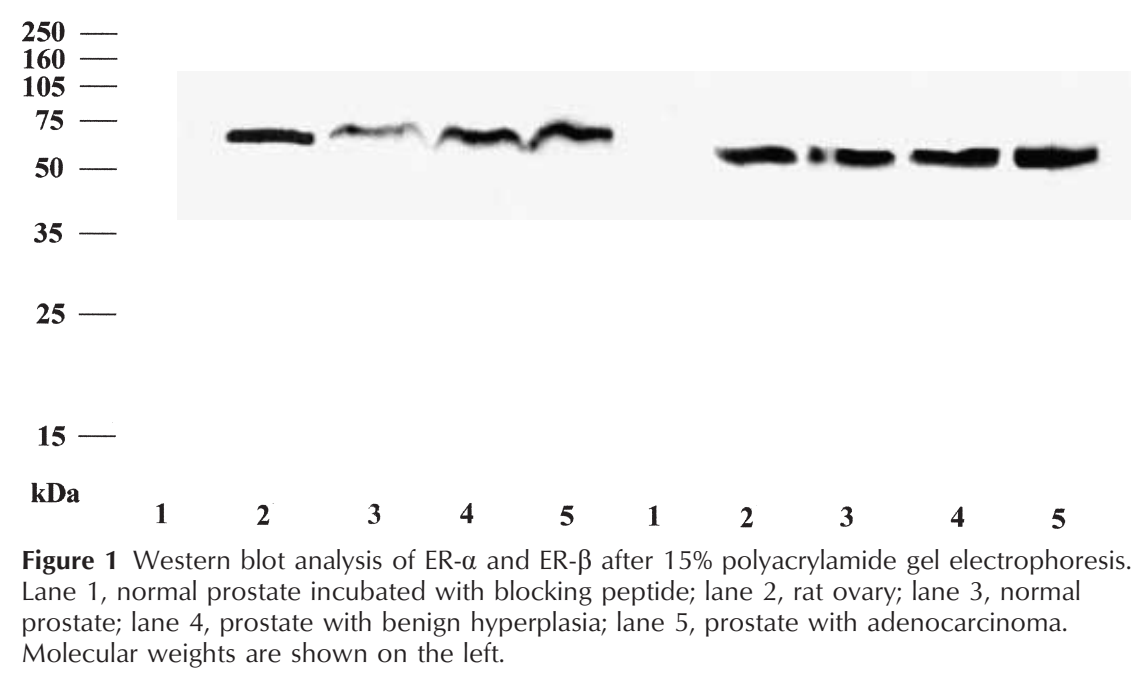

two groups of patients revealed a lower optical density in BPH $(P \leq 0 \cdot 05)$.

\section{Immunohistochemistry}

Staining of ovarian sections was always positive for the two ERs (Fig. 3). Whereas stromal cells were immunolabeled for ER- $\alpha$ (Fig. 3A), granulosa cells immunostained for ER- $\beta$ (Fig. 3B). The negative control sections incubated with preimmune sera showed no immunoreaction to either of the antibodies (Fig. 3C).

Immunostaining for ER- $\alpha$ showed differences among the three types of specimens (Fig. 3D-F and Table 2). Cell labeling was usually observed in the nuclei, and only occasionally in the cytoplasm. In normal prostates, epithelial immunostaining was absent or was limited to scattered nuclei (0.4\%) (Fig. 3D). In BPH, about $10 \%$ of epithelial cell nuclei appeared immunostained (Fig. 3E). In PC, epithelial immunostaining was more intense than in BPH (about 77\% of nuclei) and, within PC samples, no differences in the percentage of labeled cells were observed between the microglandular and the papillary patterns (Fig. 3F). In the three types of prostatic specimens about $15 \%$ of stromal cell nuclei were positively immunostained for ER- $\alpha$.

Immunostaining for ER- $\beta$ also varied with hyperplastic and neoplastic changes (Fig. 3G-I and Table 2). In the normal prostates, epithelial immunostaining was detected in about $13 \%$ of nuclei (Fig. 3G). Although most of these nuclei occupied a basal position in the epithelium, it was difficult to ascertain whether they belonged to basal cells, because many columnar cells also presented basely located nuclei, and the cell borders could not be identified by light microscopy. In $\mathrm{BPH}$, the number of labeled nuclei increased (about 30\%) and these nuclei were also in both basal and middle or more apical locations (Fig. 3H). In PC, most of the epithelial cells appeared immunostained. No immunostaining differences regarding the histological pattern (papillary or microglandular) were observed (Fig. 3I). Stromal immunostaining for ER- $\beta$ was absent in normal and hyperplastic prostates, whereas about $12 \%$ of stromal cell nuclei appeared immunostained in PC specimens.

\section{Discussion}

Previous studies demonstrating the presence of ERs in the human prostate presumably referred to the ER- $\alpha$ receptor, because the existence of a second receptor $(E R-\beta)$ was then unknown. Using immunohistochemistry, Schulze \& Claus (1990) observed ERs in some epithelial and stromal cells of the normal prostate, whereas Ehara et al. (1995) found ER mRNA and ER protein in stromal cells, but not in glandular epithelial cells. In the present study, ER- $\alpha$ protein was immunodetected in the nuclei of stromal cells and only occasionally in those of basal epithelial cells. Cytoplasmic immunolabeling was only occasionally observed, and it could be due to the presence of hormone binding transport protein (Brolin et al. 1992). In fact, in the above-mentioned immunohistochemical studies on $\mathrm{ER}$, in addition to the nucleus, the cytoplasm of some cells also appeared stained.

Biochemical studies have demonstrated that $E R-\beta$ is the predominant ER in the rat prostate (Kuiper et al. 1996, 1998, Prins et al. 1998). Our results in normal prostatic 

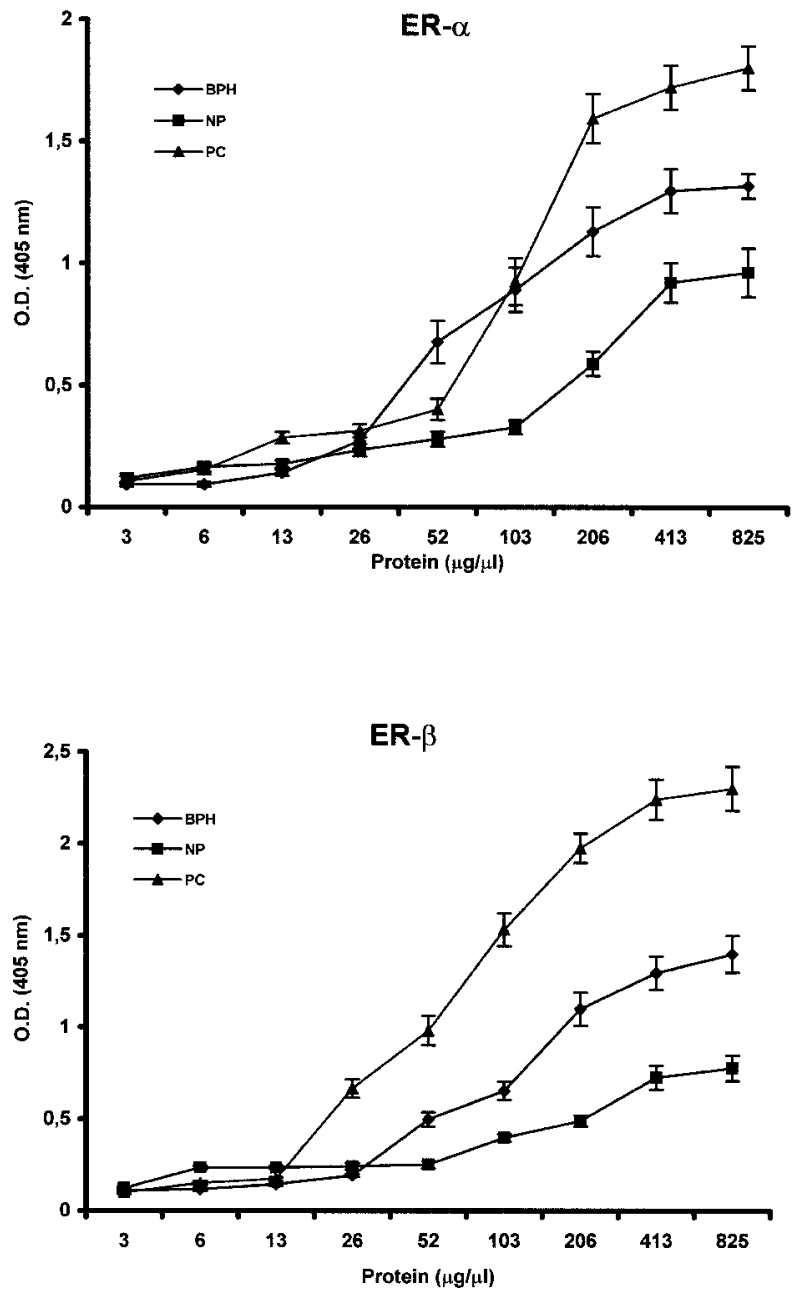

Figure 2 ELISA determinations of ER- $\alpha$ and ER- $\beta$ in normal prostate (NP), benign prostatic hyperplasia $(\mathrm{BPH})$, and prostatic carcinoma (PC). Antibody binding was followed at $405 \mathrm{~nm}$, using peroxidase-conjugated anti-mouse (ER- $\alpha$ ) or anti-goat (ER- $\beta$ ) immunoglobulins. The mean values and S.D. for each group have been calculated from all samples corresponding to the group. O.D., optical density.

tissue indicate that this receptor is only present in basal epithelial cells, whereas ER- $\alpha$ is only present in stromal cells. This complementary location of both ER types might explain why some authors (Schulze \& Claus 1990) reported the presence of ERs in both the stroma and the epithelium of normal prostates (the antibodies used reacted against both ER types). The discovery of ER- $\beta$ has made it necessary to reconsider the potential sites of estrogen action. It has been demonstrated that ER- $\alpha$ and ER- $\beta$ can activate different estrogen response elements (Pennie et al. 1998). These data support the concept that the ratio of ER- $\alpha / E R-\beta$ in a particular cell or tissue contributes to tissue specific responses to estrogens (Katzenellenbogen \& Korach 1997). Since estrogens are involved in the growth, differentiation and maintenance of the prostate (Kuiper et al. 1998), the presence of ERs in both stroma and epithelium was to be expected. Moreover, the predominant location of ER- $\beta$ in basal epithelial cells agrees with the role of these cells in epithelial growth and renewal.

Several authors have failed to detect ERs in BPH specimens (Schulze \& Claus 1990, Ehara et al. 1995), whereas Mobbs et al. (1990) found high positivity to these receptors in homogenates. Immunohistochemical studies of BPH specimens localized this receptor in basal epithelial cells (Konishi et al. 1993) or in both epithelium and stroma (Wernert et al. 1988, Wernert \& Seitz 1991, Kirschenbaum et al. 1994). This latter description agrees with the present results, which also demonstrated that epithelial immunostaining to ER- $\alpha$ was higher in $\mathrm{BPH}$ than in normal prostates. In addition, we have found that ER- $\beta$ immunoexpression was also higher in BPH than in normal prostates and, as occurs in normal prostates, immunostaining to ER- $\beta$ was mainly localized in the epithelium.

Estrogens are implicated in prostatic growth, and the hyperplastic changes seen in the prostate have been related to the exposure of prostatic tissue to increased intraprostatic and circulating estrogen levels (Zhao et al. 1992, Schweikert et al. 1993). Consequently, estrogen deprivation significantly reduces prostatic volume in $\mathrm{BPH}$ patients (Schweikert et al. 1993). Since ERs had only been identified in the prostatic stroma, it was assumed that, at the beginning of $\mathrm{BPH}$, estrogens caused proliferation of the prostatic stroma, and then the hyperplastic stroma induced epithelial cell growth, which in turn enhanced androgen action, because androgen receptors are predominantly localized in the prostatic epithelium (Bashirelahi et al. 1979, Srinivasan et al. 1995). The presence of ERs in both stroma (ER- $\alpha)$ and epithelium (ER- $\beta$ ) accounts for a direct estrogen action on the two prostatic compartments. Once BPH is stabilized, the development of both ER types in the prostatic epithelium would probably enhance estrogen action.

The presence of ERs (probably ER- $\alpha$ ) in prostate cancer (Brolin et al. 1992, Konishi et al. 1993) and in several human prostatic tumor cell lines (Carruba et al. 1994, Castagnetta \& Carruba 1995) has been well documented. The results of previous immunohistochemical comparisons of $\mathrm{PC}$ and $\mathrm{BPH}$ are discrepant. Konishi et al. (1993) found that ERs were less abundant in carcinoma specimens than in $\mathrm{BPH}$, and established a negative correlation between the presence of these receptors and malignancy. On the other hand, Mobbs et al. (1990) reported a higher number of ERs in PC than in BPH. This finding is supported by other reports that positively correlated the abundance of ERs with the degree of prostate cancer malignancy (Srinivasan et al. 1995, Bonkhoff et al. 1999). Studies in a variety of tumors including prostate cancer have led to the suggestion that estrogens favor cancer 

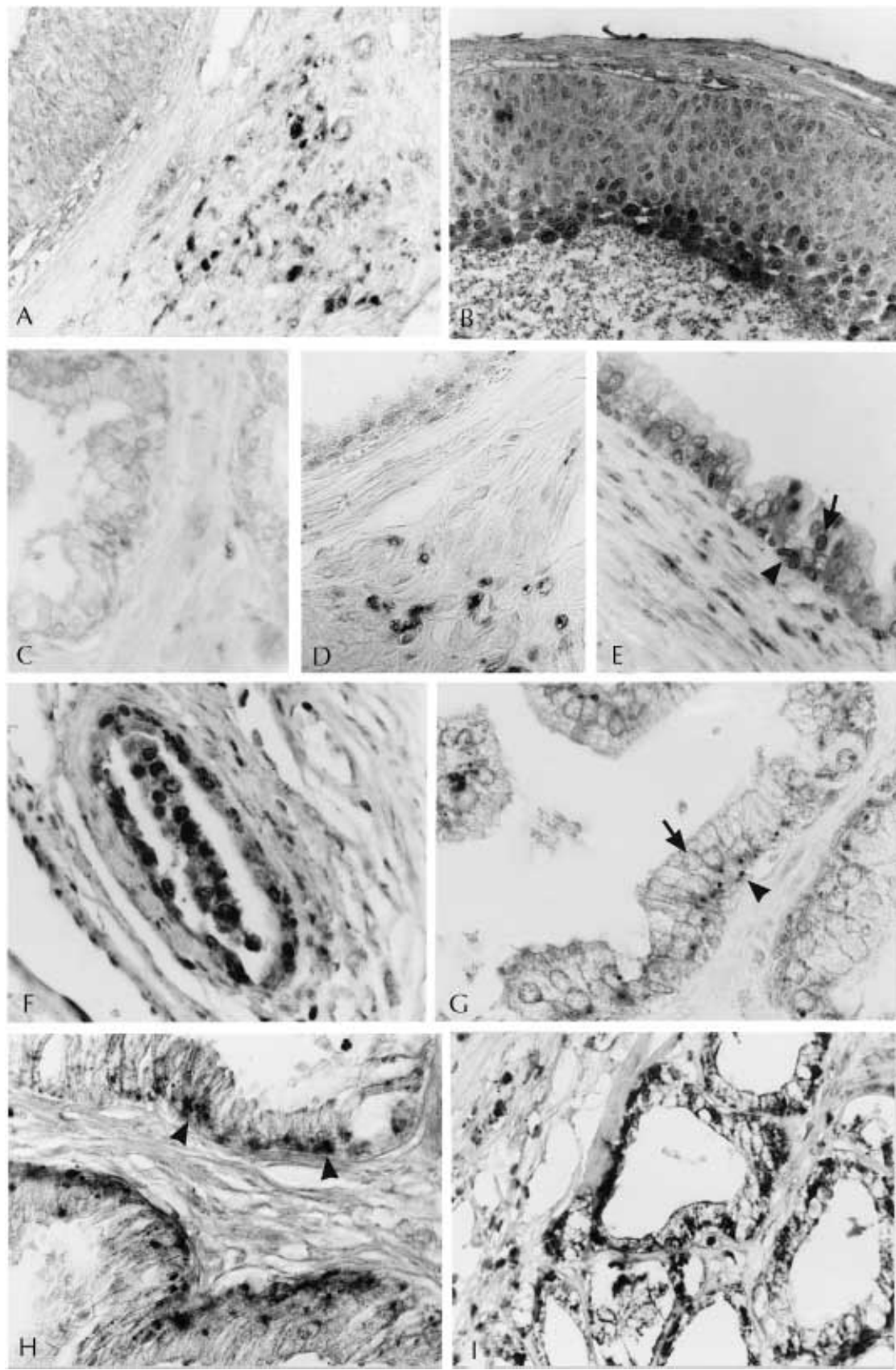

Figure 3 (A) Rat ovary immunostained for ER- $\alpha$. Only stromal cells are immunolabeled. (B) Rat ovary immunostained for ER- $\beta$. Immunoreaction is observed in granulosa cells. (C) Absence of labeling in a normal prostate incubated with ER- $\alpha$ blocking peptide (negative control). (D-F) Immunostaining for ER- $\alpha$. (D) In the normal prostate, only stromal cells are immunostained. (E) In benign prostatic hyperplasia, in addition to some stromal cells, some epithelial cell nuclei are labeled. These nuclei occupy a basal (arrowhead) or a more adluminal (arrow) position. (F) In prostatic carcinoma, most epithelial cell nuclei are immunostained. (G-I) Immunostaining for ER- $\beta$. (G) Normal prostate showing labeling in some epithelial cell nuclei which are mainly located at the base of the epithelium (arrowhead). The nuclei located in a higher position (arrow) are not immunostained. No immunostaining is detected in stromal cells. (H) Benign prostatic hyperplasia. Epithelial immunolabeling (arrowhead) is more intense than in normal prostate. (I) Prostatic carcinoma. Epithelial immunolabeling is even more intense than in benign prostatic hyperplasia. In addition, some stromal cells appear labeled. Magnification $\times 400$. 
Table 2 Comparison of immunolabeled nuclei (calculated as a percentage) in the glandular epithelium and stroma of normal prostates, benign prostatic hyperplasia, and prostatic adenocarcinoma

\begin{tabular}{|c|c|c|}
\hline & ER-a (\%) & ER- $\boldsymbol{\beta}(\%)$ \\
\hline \multicolumn{3}{|l|}{ Prostate } \\
\hline \multicolumn{3}{|l|}{ Normal } \\
\hline Stroma & $15 \cdot 8 \pm 2 \cdot 2^{\mathrm{a}}$ & - \\
\hline Epithelium & $0 \cdot 4 \pm 0 \cdot 1^{b}$ & $12 \cdot 9 \pm 2 \cdot 6^{\mathrm{e}}$ \\
\hline \multicolumn{3}{|l|}{$\mathrm{BPH}$} \\
\hline Stroma & $15 \cdot 3 \pm 2 \cdot 5^{a}$ & $0 \cdot 3 \pm 0 \cdot 1^{f}$ \\
\hline Epithelium & $10 \cdot 1 \pm 2 \cdot 12^{\mathrm{C}}$ & $29 \cdot 9 \pm 3 \cdot 4^{8}$ \\
\hline \multicolumn{3}{|l|}{ Cancer } \\
\hline Stroma & $16 \cdot 3 \pm 5 \cdot 4^{\mathrm{a}}$ & $12 \cdot 3 \pm 2 \cdot 8$ \\
\hline Epithelium & $76 \cdot 8 \pm 7 \cdot 5^{d}$ & $79 \cdot 8 \pm 8 \cdot 9^{h}$ \\
\hline Papillary & $71 \cdot 3 \pm 7 \cdot 4^{d}$ & $80 \cdot 2 \pm 8 \cdot 7^{h}$ \\
\hline Microglandular & $79 \cdot 6 \pm 7 \cdot 7^{d}$ & $78 \cdot 4 \pm 8 \cdot 6^{h}$ \\
\hline
\end{tabular}

For each receptor, values with a different superscript letter differ significantly $(P \leq 0 \cdot 05)$. The mean values and S.D. for each group have been calculated from all samples corresponding to the group.

development by stimulation of cell proliferation (Yager \& Liehr 1996).

Recently, Bonkhoff et al. (1999) used immunohistochemical and in situ hybridization methods to study the presence of both ER- $\alpha$ and ER- $\beta$ in human prostatic cancer and in premalignant prostatic lesions and failed to demonstrate the ER- $\beta$ type. The discrepancy between these results and those of the present report might be attributed to the fact that the antibody used was acquired from a different purchaser; and/or to the method of tissue processing. In our study, the specificity of both types of ERs was checked by both negative and positive controls. The latter were performed in ovarian tissue and revealed that while ER- $\alpha$ labeled stromal cells, ER- $\beta$ labeled granulosa cells.

Present results revealed that epithelial immunostaining to both ER- $\alpha$ and ER- $\beta$ is more intense in PC than in $\mathrm{BPH}$. In addition, some stromal cells acquire ER- $\beta$ which is absent in normal prostates and in $\mathrm{BPH}$. These findings suggest that both ERs take part in prostate cancer, although the involvement of estrogen receptors concerns mainly the epithelium.

In summary, our data suggest that, in the normal prostate, estrogen action is mediated by ER- $\alpha$ in the stromal compartment, and by ER- $\beta$ in the epithelial compartment where it specifically regulates basal cell proliferation. The presence of ERs in both stroma (ER- $\alpha$ ) and epithelium (ER- $\beta$ ) accounts for a direct estrogen action on the two prostatic compartments. The increased epithelial immunostaining for both ER- $\alpha$ and $E R-\beta$ in $\mathrm{BPH}$ and PC suggests that the involvement of estrogen receptors in hyperplasia and cancer concerns mainly the epithelium.

\section{Acknowledgements}

This work was supported by grants from the Fondo de Investigaciones Sanitarias (98/028), University of Alcalá, and Sociedad Madrileña de Urología.

\section{References}

Bashirelahi N, Young JD, Sidh SM \& Sanefuji H 1979 Androgen, oestrogen, and progesterone and their distribution in epithelial and stromal cells of human prostate. In Steroids Receptors, Metabolism and Prostate Cancer, pp 240-256. Eds FH Schroeder \& HJ de Voogt. Amsterdam: Excerpta Medica.

Bonkhoff H, Fixemer T, Hunsicker I \& Remberger K 1999 Estrogen receptor expression in prostate cancer and premalignant prostatic lesions. American Journal of Pathology 155 641-547.

Bradford MM 1976 A rapid and sensitive method for the quantitation of microgram quantities of protein utilizing the principle of protein dye binding. Annals of Biochemistry 72 248-254.

Brolin J, Skoong L \& Ekman P 1992 Immunohistochemistry and biochemistry in detection of androgen, progesterone, and estrogen receptors in benign and malignant human prostatic tissue. Prostate 20 281-295.

Byers M, Kuiper GGJM, Gustafsson JA \& Park-Sarge OK 1997 Estrogen receptor $\beta$ mRNA expression in rat ovary: downregulation by gonadotropins. Molecular Endocrinology 11 172-182.

Carruba G, Pfeffer U, Fecarotta E, Coviello D, D'Amato E, Lo-Casto M, Vidali G \& Castagnetta L 1994 Estradiol inhibits growth of hormone-nonresponsive PC3 human prostate cancer cells. Cancer Research 54 1190-1193.

Castagnetta L \& Carruba G 1995 Human prostate cancer: a direct role for oestrogens. In Non-Reproductive Actions of Sex Steroids, Ciba Foundation Symposium 191, pp 269-289. Chichester: Wiley.

Cox RL \& Crawford D 1995 Estrogens in the treatment of prostate cancer. Journal of Urology 154 1991-1998.

Ehara H, Koiji T, Deguchi T, Yoshii A, Nakano M, Nakane P \& Kawada Y 1995 Expression of receptor in diseased human prostate assessed by non-radioactive in situ hybridization and immunohistochemistry. Prostate 27 304-313.

Green GL, Glina P, Waterfield M, Baker A, Hort Y \& Shine J 1986 Sequence and expression of human estrogen receptor complementary DNA. Science 231 1150-1154.

Hobisch A, Hittmair A, Daxenbichler G, Wille S, Radmayr C, Hobisch-Hagen P, Klocker H \& Culig Z 1997 Metastatic lesions from prostate cancer do not express oestrogen and progesterone receptors. Journal of Pathology 182 356-361.

Hsu SM \& Soban E 1982 Colour modification of diaminobenzidine $(\mathrm{DAB})$ precipitation by metallic ions and its application to double immunohistochemistry. Journal of Histochemistry and Cytochemistry 30 1079-1082.

Hsu SM, Reiner L \& Fanger H 1981 Use of avidin-biotin-peroxidase complex $(\mathrm{ABC})$ in immunoperoxidase technique. A comparison and unlabeled antibody PAP procedures. Journal of Histochemistry and Cytochemistry 29 577-580.

Katzenellenbogen BS \& Korach KS 1997 A new actor in the estrogen receptor drama: enter ER $\beta$. Endocrinology 138 861-862.

Kirschenbaum A, Ren M, Erenburg I, Schater B \& Levine AC 1994 Estrogen receptor messenger RNA expression in human benign prostatic hyperplasia: detection, localization, and modulation with a long-acting gonadotropin-releasing hormone agonist. Journal of Andrology 15 528-533.

Koike S, Sakai M \& Muramatsu M 1987 Molecular cloning and characterization of rat estrogen receptor cDNA. Nucleic Acids Research 15 2499-2513. 
Konishi N, Nakaoka S, Kitahori Y, Ohshima M, Samma S \& Okajima E 1993 Immunohistochemical evaluation of estrogen receptor status in benign prostatic hypertrophy and in prostate carcinoma and the relationship to efficacy of endocrine therapy. Oncology 50 259-263.

Kuiper G, Enmark E, Pelto-Huikko M, Nilsson S \& Gustafsson J 1996 Cloning of a novel estrogen receptor expressed in rat prostate and ovary. PNAS 93 5925-5930.

Kuiper G, Shughrue P, Merchenthaler I \& Gustafsson J 1998 The estrogen receptor $\beta$ subtype: a novel mediator of estrogen action in neuroendocrine systems. Frontiers in Neuroendocrinology 19 253-286.

Mobbs BG, Johson IE \& Liu Y 1990 Quantitation of cytosolic and nuclear estrogen and progesterone receptor in benign, untreated, and treated malignant human prostatic tissue by radioligand binding and enzyme-immunoassays. Prostate 16 235-244.

Mosselman S, Polman J \& Dijkema R 1996 ER $\beta$ : identification and characterization of a novel human estrogen receptor. FEBS Letters 392 49-53.

Pennie WD, Aldridge TC \& Brooks AN 1998 Differential activation by xenoestrogens of $E R \alpha$ and $E R \beta$ when linked to different response elements. Journal of Endocrinology 158 R11-R14.

Prins GS, Marmer M, Woodham C, Chang W, Kuiper G, Gustafsson J \& Birch L 1998 Estrogen receptor- $\beta$ messenger ribonucleic acid ontogeny in the prostate of normal and neonatally estrogenized rats. Endocrinology 139 874-883.

Schulze H \& Claus S 1990 Histological localization of estrogen receptors in normal and diseased human prostates by immunocytochemistry. Prostate 16 331-343.
Schweikert HU, Tunn UW, Habenicht UF, Arnold J, Senge H, Schulze H, Schröder FH, Blom JHM, Enmemoser O, Horniger W \& Bartsch G 1993 Effects of estrogen deprivation on human benign prostatic hyperplasia. Journal of Steroid Biochemistry and Molecular Biology 44 573-576.

Srinivasan G, Campbell E \& Bashirelahi N 1995 Androgen, estrogen and progesterone receptors in normal and aging prostate. Microscopy Research and Technique 30 293-304.

Wernert N \& Seitz G 1991 Prostatic cancer. Immunohistochemistry of steroid hormone receptors. Current Topic in Pathology 83 475-494.

Wernert N, Gerdes J, Loy V, Seitz G, Scherr O \& Dhom G 1988 Investigations of the estrogen (ER-ICA-test) and the progesterone receptor in the prostate and prostatic carcinoma on immunohistochemical basis. Virchows Archiv Pathology A: Anatomy and Histopathology 412 387-391.

Yager JD \& Liehr JG 1996 Molecular mechanisms of estrogen carcinogenesis. Annual Review of Pharmacology and Toxicology 36 203-232.

Zhao GQ, Holterthus PM, Dammshä user I, Hoffbauer G \& Aumüller G 1992 Estrogen-induced morphological and immunohistochemical changes in stroma and epithelium of rat ventral prostate. Prostate 21 183-189.

Received 14 August 2000

Accepted 1 November 2000 